\title{
Synthesis of Cinnamanilide Derivatives and Their Antioxidant and Antimicrobial Activity
}

\author{
Satish Balasaheb Nimse, ${ }^{1}$ Dilipkumar Pal, ${ }^{2}$ Avijit Mazumder, ${ }^{3}$ and Rupa Mazumder ${ }^{3}$ \\ ${ }^{1}$ Institute for Applied Chemistry and Department of Chemistry, Hallym University, Chuncheon 24252, Republic of Korea \\ ${ }^{2}$ Institute of Pharmaceutical Sciences, Guru Ghasidas Vishwavidyalaya, Bilaspur, Chhattisgarh 495009, India \\ ${ }^{3}$ Department of Pharmaceutical Technology, Noida Institute of Engineering and Technology, Greater Noida 201306, India
}

Correspondence should be addressed to Satish Balasaheb Nimse; satish_nimse@hallym.ac.kr

Received 12 October 2015; Revised 2 December 2015; Accepted 7 December 2015

Academic Editor: Artur M. S. Silva

Copyright (C) 2015 Satish Balasaheb Nimse et al. This is an open access article distributed under the Creative Commons Attribution License, which permits unrestricted use, distribution, and reproduction in any medium, provided the original work is properly cited.

\begin{abstract}
The amide derivatives of cinnamic acid were synthesized and their antimicrobial and antioxidant activities were investigated. The investigation of antimicrobial potentials of the compounds demonstrated a strong activity against 21 bacterial strains comprising Gram-positive and Gram-negative bacteria. Compounds $\mathbf{2 a}, \mathbf{2} \mathbf{b}$, and $\mathbf{3 b}$ showed strong antimicrobial activity against all microorganisms with the pMIC value ranging from 2.45 to 3.68. Compounds $\mathbf{2 a}, \mathbf{3 a}$, and $\mathbf{3 b}$ demonstrated strong antioxidant activity with \% inhibition of the DPPH radical of $51 \%( \pm 1.14), 41 \%( \pm 1.01)$, and $50 \%( \pm 1.23)$, respectively. These findings indicate that the amide derivatives of the cinnamic acid possess strong antibacterial and antioxidant activities.
\end{abstract}

\section{Introduction}

Discovery of simple organic compounds with the antimicrobial and antioxidant activities is of growing concern in the food industries for their preservative properties [1,2]. Preservation of industrial food containing polyunsaturated fatty acids (eicosapentaenoic $(20: 5 \omega-3)$ acid) has been a subject of growing interest, because of their importance in human nutrition. $\omega$-3-Polyunsaturated fatty acids have several health benefits in cardiovascular disease, immune disorders, inflammation, allergies, and diabetes [3]. Therefore, the development of the antimicrobial compounds that can act as food preservatives by inhibiting the growth of bacteria or fungi, including mold, is very important [4].

Apart from the bacterial deterioration, the radical associated oxidation of fatty acids is one of the most important reactions leading to a degeneration of food $[5,6]$. Several compounds with the antioxidant activity have been used to slow down the radical associated oxidative reactions. Antioxidants are molecules that inhibit or quench free radical reactions and delay or inhibit the cellular damage $[7,8]$. The butylated hydroxyanisole (BHA), butylated hydroxytoluene (BHT), and tertiary butylhydroquinone (TBHQ) have been used commonly as food antioxidants. However, some of these molecules are known to possess toxic and carcinogenic side effects in animal models [9]. Therefore, the demand has increased because of questions about the long-term safety and negative consumer perception of the commonly used synthetic antioxidants BHT and BHA. The discovery of compounds that can show both antimicrobial and antioxidant activities with no toxic effects on health is highly awaited.

Due to its common occurrence in plants and its low toxicity $[10,11]$, cinnamic acid has been evaluated as an antioxidant compound $[12,13]$. Moreover, the cinnamic acid derivatives are reported to possess better antimicrobial activity than cinnamic acid itself $[14,15]$. In the present paper the synthesis, antimicrobial, and antioxidant activities of the amide derivatives of cinnamic acid are presented.

\section{Materials and Methods}

All chemicals, solvents, and biochemical reagents were of analytical grade and purchased from commercial sources. 1,1-Diphenyl-2-picrylhydrazyl (DPPH) was purchased from Aldrich Chemical Co. (Milwaukee, WI, USA). UV-Vis spectra were obtained on a Perkin-Elmer 554 double beam spectrophotometer. The final products were characterized by ${ }^{1} \mathrm{H}$ 


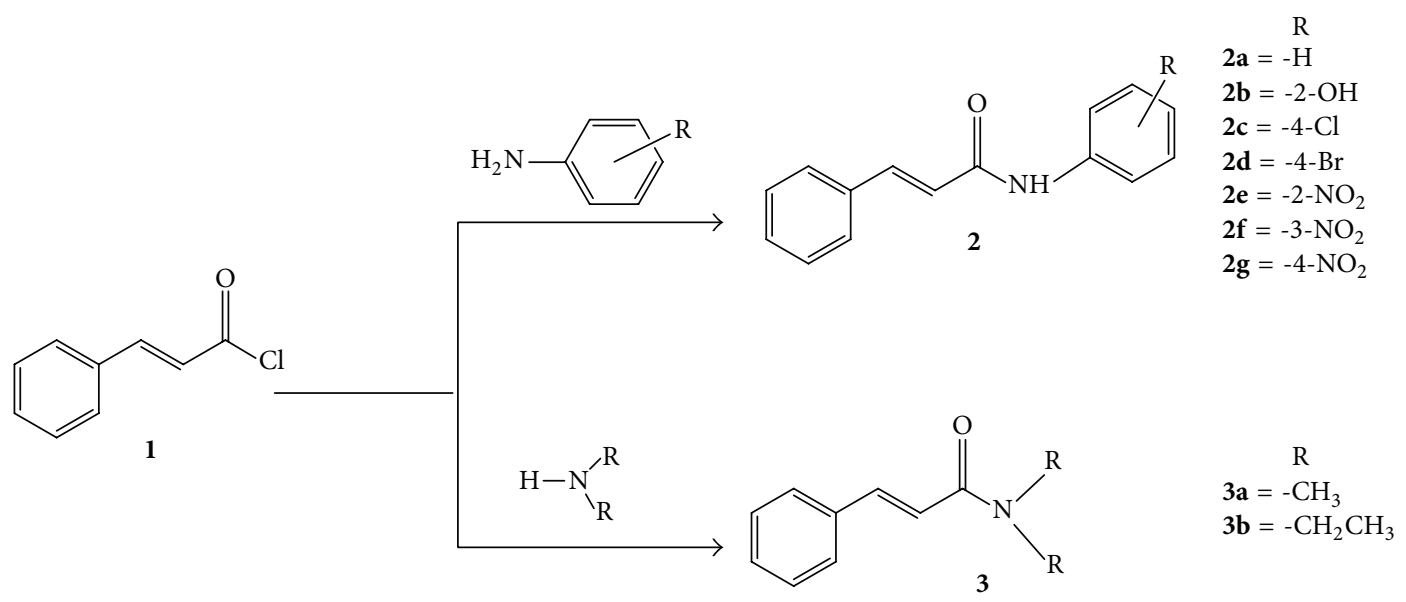

SCHEME 1: Synthesis of compounds $\mathbf{2} \mathbf{a}-\mathbf{2} \mathbf{g}$ and $\mathbf{3 a} \mathbf{a} \mathbf{3} \mathbf{b}$.

and ${ }^{13} \mathrm{C}$ NMR (JEOL FX-90Q FT NMR, $300 \mathrm{MHz}$ ) and mass spectrometry (JEOL JMS 600 Mass Spectrometer).

2.1. General Procedure for the Synthesis of Compounds $\mathbf{2 a - 2 g}$ and $\mathbf{3 a - 3} \mathbf{b}$. Compounds $\mathbf{2} \mathbf{a}-\mathbf{2} \mathbf{d}$ and $\mathbf{3 a} \mathbf{a} \mathbf{3} \mathbf{b}$ (Scheme 1) were synthesized by slight modification of the typical procedure adopted for various cinnamic acid derivatives [16, 17]. To a stirred solution containing aniline derivatives or amine derivatives ( $25 \mathrm{mmol}), \mathrm{K}_{2} \mathrm{CO}_{3}(4.15 \mathrm{~g}, 30 \mathrm{mmol}$ ), and tetrahydrofuran $(30 \mathrm{~mL})$, the cinnamoyl chloride $(4.10 \mathrm{~g}, 20 \mathrm{mmol})$ dissolved tetrahydrofuran $(5 \mathrm{~mL})$ was added dropwise at $0^{\circ} \mathrm{C}$. The mixture was stirred at $0^{\circ} \mathrm{C}$ for $30 \mathrm{~min}$ and then at RT for 3 hours. The solution was concentrated under vacuum and then poured on ice cold water with stirring. The precipitated product was washed with water and dried in an oven at $100^{\circ} \mathrm{C}$. The final compounds were then obtained by crystallization from ethanol.

For the synthesis of compounds $\mathbf{2 e - 2 g}$, to a stirred solution of respective aniline derivatives $(30 \mathrm{mmol})$ in diethyl ether $(30 \mathrm{~mL})$, the cinnamoyl chloride $(4.10 \mathrm{~g}, 20 \mathrm{mmol})$ dissolved in diethyl ether $(5 \mathrm{~mL})$ was added dropwise at $0^{\circ} \mathrm{C}$. The mixture was stirred at $0^{\circ} \mathrm{C}$ for $30 \mathrm{~min}$ and then at RT for 3 hours. After completion of reaction the solvent was concentrated and then added to $100 \mathrm{~mL}$ of dichloromethane. The solution was washed 3 times with $1 \mathrm{~N} \mathrm{HCl}$ and 2 times with $1 \mathrm{~N} \mathrm{NaHCO}_{3}$. The separated organic layer was dried over $\mathrm{Mg}_{2} \mathrm{SO}_{4}$ and solvent was evaporated completely to obtain a residue. The final compounds were obtained by crystallization from ethanol.

(2a) N-Phenylcinnamamide. $75.55 \%$ yield, ${ }^{1} \mathrm{H} \mathrm{NMR}\left(\mathrm{CDCl}_{3}\right.$, $300 \mathrm{MHz}, 298 \mathrm{~K}) \delta(\mathrm{ppm}): 9.74(\mathrm{~s}, 1 \mathrm{H},-\mathrm{NH}), 7.57(\mathrm{~m}, 10 \mathrm{H}$, Ar-H), $7.50(\mathrm{~d}, 1 \mathrm{H}, J=15.6 \mathrm{~Hz}, \mathrm{CH}=\mathrm{CH}), 6.72(\mathrm{~d}, 1 \mathrm{H}$, $J=15.6 \mathrm{~Hz}, \mathrm{CH}=\mathrm{CH}) .{ }^{13} \mathrm{C} \mathrm{NMR}\left(300 \mathrm{MHz} \mathrm{CDCl}_{3}\right): 163.66$ $(\mathbf{C}=\mathrm{O}), 140.32$ (Ar- $\mathrm{CH}=\mathrm{CH}), 139.16,134.86,129.42,128.90$, 128.11, 127.52, 122.31 (Ar), $121.62(\mathrm{CH}=\mathrm{CH}-\mathrm{C}=\mathrm{O})$. JEOL JMS 600, $\mathrm{EI}^{+}$mode: $m / z=223.2089[\mathrm{M}]^{+}, 224.2087[\mathrm{M}+\mathrm{H}]^{+}$.

(2b) N-(2-Hydroxyphenyl)cinnamamide. 50.76\%, ${ }^{1} \mathrm{H}$ NMR (d6-DMSO, $300 \mathrm{MHz}, 298 \mathrm{~K}) \delta$ (ppm): 10.03 (bs, 1H, -NH),
9.52, (s, 1H, - OH), $7.96(\mathrm{~d}, 1 \mathrm{H}, J=15.6 \mathrm{~Hz}, \mathrm{CH}=\mathrm{CH}), 7.38-$ 7.65 (m, 6H, Ar-H), 7.18 (d, 1H, $J=15.6 \mathrm{~Hz}, \mathrm{CH}=\mathrm{CH}), 6.90-$ 6.96 (dt, 2H, Ar-H), 6.81 (t, 1H, Ar-H). ${ }^{13} \mathrm{C} \mathrm{NMR}$ (d6-DMSO, $300 \mathrm{MHz}, 298 \mathrm{~K}): 164.6(\mathbf{C}=\mathrm{O}), 148.3\left(\mathrm{HO}-\mathrm{Ar}_{-\mathrm{C}}\right)$, 140.7 (Ar$\mathrm{CH}=\mathrm{CH}), 135.5,130.2,129.5,128.5,128.3,127.3,125.1,123.3$, 122.5, $116.2(\mathrm{Ar}), 119.5(\mathrm{CH}=\mathrm{CH}-\mathrm{C}=\mathrm{O})$. JEOL JMS 600, $\mathrm{EI}^{+}$ mode: $m / z=239.2945[\mathrm{M}]^{+}, 240.2946[\mathrm{M}+\mathrm{H}]^{+}$.

(2c) N-(4-Chlorophenyl)cinnamamide. $76.65 \%$ yield, ${ }^{1} \mathrm{H}$ $\mathrm{NMR}\left(\mathrm{CDCl}_{3}, 300 \mathrm{MHz}, 298 \mathrm{~K}\right) \delta(\mathrm{ppm}): 7.76(\mathrm{~d}, 1 \mathrm{H}$, $J=15.6 \mathrm{~Hz}, \mathrm{CH}=\mathrm{CH}), 7.62-7.60(\mathrm{~m}, 4 \mathrm{H}, \mathrm{Ar}-\mathrm{H}), 7.52(\mathrm{~d}, 2 \mathrm{H}$, Ar-H), 7.41-7.39 (m, 3H, Ar-H), 7.33 (br, 1H, -NH), 6.58 (d, $J=15.6 \mathrm{~Hz}, 1 \mathrm{H}, \mathrm{CH}=\mathrm{CH}) .{ }^{13} \mathrm{C} \mathrm{NMR}\left(300 \mathrm{MHz}, \mathrm{CDCl}_{3}\right)$ : $164.0(\mathrm{C}=\mathrm{O}), 142.9$ (Ar- $\mathrm{CH}=\mathrm{CH}), 136.6,134.5$ (Ar), 130.2 $\left(\mathrm{Cl}-\mathrm{Ar}_{-\mathrm{C}}\right), 129.1,129.04,128.9,121.2(\mathrm{Ar}-\mathrm{C}), 120.04(\mathrm{CH}=\mathrm{CH}-$ $\mathrm{C}=\mathrm{O})$. JEOL JMS 600, $\mathrm{EI}^{+}$mode: $m / z=257.7134[\mathrm{M}]^{+}$, 258.7136 $[\mathrm{M}+\mathrm{H}]^{+}$.

(2d) $\mathrm{N}$-(4-Bromophenyl)cinnamamide. $70.45 \%$ yield, ${ }^{1} \mathrm{H}$ $\mathrm{NMR}\left(\mathrm{CDCl}_{3}, 300 \mathrm{MHz}, 298 \mathrm{~K}\right) \delta$ (ppm): 7.79 (d, $1 \mathrm{H}, J=$ $15.6 \mathrm{~Hz}, \mathrm{CH}=\mathrm{CH}), 7.57-7.54(\mathrm{~m}, 4 \mathrm{H}, \mathrm{Ar}-\mathrm{H}), 7.49$ (d, 2H, ArH), 7.43-7.41 (m, 3H, Ar-H), 7.34 (br, 1H, -NH) 6.55 (d, 1H, $J=15.6 \mathrm{~Hz}, \mathrm{CH}=\mathrm{CH}) .{ }^{13} \mathrm{C} \mathrm{NMR}\left(300 \mathrm{MHz}, \mathrm{CDCl}_{3}\right): 164.1$ $(\mathbf{C}=\mathrm{O}), 141.0$ (Ar-CH=CH), 138.0, 132.2, 130.1, 129.5, 129.3, 128.1 (Ar), $121.5\left(\mathrm{Br}_{-} \mathrm{Ar}_{-\mathrm{C}}\right), 119.7(\mathrm{CH}=\mathrm{CH}-\mathrm{C}=\mathrm{O})$. JEOL JMS 600, $\mathrm{EI}^{+}$mode: $m / z=302.1662[\mathrm{M}]^{+}, 303.1664[\mathrm{M}+\mathrm{H}]^{+}$.

(2e) $\mathrm{N}$-(2-Nitrophenyl) cinnamamide. $70.34 \%$ yield. ${ }^{1} \mathrm{H}$ NMR $\left(\mathrm{CDCl}_{3}, 300 \mathrm{MHz}, 298 \mathrm{~K}\right) \delta(\mathrm{ppm}), 10.61$ (br, $\left.1 \mathrm{H},-\mathrm{NH}\right), 8.92$ $(1 \mathrm{H}, \mathrm{d}, J=7.8 \mathrm{~Hz}, \mathrm{Ar}-\mathrm{H}), 8.22(1 \mathrm{H}, \mathrm{d}, J=8.4 \mathrm{~Hz}, \mathrm{Ar}-\mathrm{H}), 7.75$ $(\mathrm{d}, 1 \mathrm{H}, J=15.6 \mathrm{~Hz}, \mathrm{CH}=\mathrm{CH}), 7.64-7.70(\mathrm{t}, 1 \mathrm{H}, \mathrm{Ar}-\mathrm{H}), 7.56-$ 7.59 (dd, 2H, Ar-H), 7.39-7.41 (m, 3H, Ar-H), 7.17-7.20 (t, 1H, Ar-H), $6.58(\mathrm{~d}, 1 \mathrm{H}, J=15.6 \mathrm{~Hz}, \mathrm{CH}=\mathrm{CH}) .{ }^{13} \mathrm{C} \mathrm{NMR}(\mathrm{d} 6-$ DMSO, $300 \mathrm{MHz}$ ): 164.9 (C=O), $144.2\left(\mathrm{NO}_{2}-\mathrm{Ar}_{-\mathrm{C}}\right), 136.9$ $(\mathrm{Ar}-\mathrm{CH}=\mathrm{CH}), 136.4,135.8,134.8,130.9,129.5,128.7,126.3$, 123.6, 122.8 (Ar), $121.6(\mathrm{CH}=\mathrm{CH}-\mathrm{C}=\mathrm{O})$. JEOL JMS 600, $\mathrm{EI}^{+}$ mode: $m / z=268.2617[\mathrm{M}]^{+}$.

(2f) N-(3-Nitrophenyl)cinnamamide. $72.95 \%$ yield, ${ }^{1} \mathrm{H}$ NMR (d6-DMSO, $300 \mathrm{MHz}, 298 \mathrm{~K}) \delta$ (ppm), 10.68 (br, 1H, -NH), 8.77 (1H, s, Ar-H), 8.02 (d, 1H, $J=7.8 \mathrm{~Hz}$, Ar-H), 7.89 (d, 
TABLE 1: Antimicrobial activity of compounds $\mathbf{2 a} \mathbf{a} \mathbf{- 2} \mathbf{g}$ and $\mathbf{3 a - 3} \mathbf{b}$.

\begin{tabular}{|c|c|c|c|c|c|c|c|c|c|}
\hline \multirow{2}{*}{ Microbial strain } & \multicolumn{9}{|c|}{ pMIC } \\
\hline & $2 a$ & $2 b$ & $2 c$ & $2 d$ & $2 \mathrm{e}$ & $2 f$ & $2 \mathrm{~g}$ & $3 a$ & $3 b$ \\
\hline E. coli K99 & 2.45 & 3.68 & 2.81 & 2.58 & 2.83 & 3.13 & $*$ & $*$ & $*$ \\
\hline E. coli 306 & 2.45 & 3.38 & 2.81 & 2.88 & 2.83 & 2.83 & * & 2.41 & $*$ \\
\hline E. coli $K 88$ & 2.45 & 3.68 & 3.11 & 2.58 & 3.13 & 2.83 & * & * & $*$ \\
\hline E. coli LT37 & 3.95 & 3.68 & 4.41 & 2.58 & 4.03 & 4.43 & 4.03 & 3.61 & 3.85 \\
\hline E. coli 872 & 2.75 & 3.68 & 2.81 & 2.58 & 3.13 & 2.83 & * & * & 3.54 \\
\hline E. coli $R O W 7 / 12$ & 2.75 & 3.68 & 3.11 & 2.58 & 2.83 & 3.13 & 2.83 & * & $*$ \\
\hline E. coli 3:37C & 2.75 & 3.68 & 2.81 & 2.58 & 2.83 & 2.53 & 2.53 & * & 2.34 \\
\hline E. coli CD/99/1 & 2.75 & 3.38 & 3.11 & 2.58 & 2.83 & 3.13 & 2.53 & * & 2.34 \\
\hline Salmonella TyphiTy2 & 3.95 & 3.68 & 2.51 & * & $*$ & * & 2.53 & * & 2.64 \\
\hline Shigella dysenteriae 1 & * & 2.78 & 2.51 & * & 2.53 & 2.53 & 2.83 & * & 2.94 \\
\hline Shigella dysenteriae 8 & * & 3.68 & 2.51 & * & 2.83 & 2.53 & 3.13 & * & 2.94 \\
\hline Shigella sonnei 1 & * & 2.78 & * & * & 2.53 & * & 3.83 & 2.71 & 2.64 \\
\hline Shigella boydii D13629 & * & 3.08 & 2.51 & * & 2.53 & * & 2.53 & * & 3.85 \\
\hline Shigella flexneri Type 6 & * & 3.08 & 2.51 & * & 2.53 & 2.53 & 3.13 & 2.71 & 2.94 \\
\hline Vibrio cholerae 1313 & 2.45 & 3.68 & 3.11 & * & 2.53 & 2.53 & 2.53 & * & $*$ \\
\hline Vibrio cholerae 293 & 2.45 & 3.38 & 3.11 & 2.58 & 2.53 & 2.83 & 2.53 & 2.41 & 2.34 \\
\hline Vibrio cholerae 1315 & 3.05 & 3.38 & 3.11 & 2.58 & 3.13 & 2.83 & 3.13 & * & $*$ \\
\hline Vibrio cholerae 85 & 3.95 & 3.38 & 3.11 & 2.58 & 4.03 & 2.53 & 2.83 & 3.31 & 2.94 \\
\hline Staphylococcus aureus ML267 & * & 2.78 & 2.51 & * & * & 4.03 & 3.43 & * & 2.94 \\
\hline Bacillus pumilus 82 & 2.75 & 3.38 & * & $*$ & $*$ & 2.53 & $*$ & 3.01 & 3.24 \\
\hline Bacillus subtilis ATCC 6633 & 3.95 & 3.68 & 3.71 & $*$ & $*$ & 2.53 & $*$ & * & $*$ \\
\hline
\end{tabular}

${ }^{*}$ No antimicrobial activity was observed in the concentration range of $5-800 \mu \mathrm{g} / \mathrm{mL}$.

$1 \mathrm{H}, J=7.8 \mathrm{~Hz}, \mathrm{Ar}-\mathrm{H}), 7.44-7.72(\mathrm{~m}, 7 \mathrm{H}, \mathrm{Ar}-\mathrm{H}, \mathrm{CH}=\mathrm{CH})$, $6.82(\mathrm{~d}, 1 \mathrm{H}, J=15.6 \mathrm{~Hz}, \mathrm{CH}=\mathrm{CH}) .{ }^{13} \mathrm{C}$ NMR $(\mathrm{d} 6-\mathrm{DMSO}$, $300 \mathrm{MHz}): 164.6(\mathrm{C}=\mathrm{O}), 148.5\left(\mathrm{NO}_{2}-\mathrm{Ar}_{-\mathrm{C}}\right), 141.6(\mathrm{Ar}-$ $\mathrm{CH}=\mathrm{CH}), 140.9,135.0,130.4,129.4,128.3,125.6,122.1,113.9$ (Ar), $118.1(\mathrm{CH}=\mathrm{CH}-\mathrm{C}=\mathrm{O})$. JEOL JMS $600, \mathrm{EI}^{+}$mode: $m / z=$ $268.2615[\mathrm{M}]^{+}$.

(2g) $\mathrm{N}$-(4-Nitrophenyl) cinnamamide. $68.23 \%$ yield, ${ }^{1} \mathrm{H}$ NMR (d6-DMSO, $300 \mathrm{MHz}, 298 \mathrm{~K}) \delta$ (ppm): $10.90(\mathrm{~s}, 1 \mathrm{H},-\mathrm{NH})$, $8.22(\mathrm{~d}, 2 \mathrm{H}, J=8.7 \mathrm{~Hz}, \mathrm{Ar}-\mathrm{H}), 7.93(\mathrm{~d}, 2 \mathrm{H}, J=7.8 \mathrm{~Hz}, \mathrm{Ar}-\mathrm{H})$, 7.69-7.43 (m, 6H, Ar- $\mathrm{H}, \mathrm{CH}=\mathrm{CH}), 6.85(\mathrm{~d}, 1 \mathrm{H}, J=15.0 \mathrm{~Hz}$, $\mathrm{CH}=\mathrm{CH}) .{ }^{13} \mathrm{C}$ NMR (d6-DMSO, $\left.300 \mathrm{MHz}\right): 164.9(\mathrm{C}=\mathrm{O})$, 146.1 $\left(\mathrm{NO}_{2}-\mathrm{Ar}_{-\mathrm{C}}\right), 142.8,142.4(\mathrm{Ar}), 142.2(\mathrm{Ar}-\mathrm{CH}=\mathrm{CH}), 135.0$, $129.5,128.5,125.7,121.9(\mathrm{Ar}-\mathrm{C}), 119.6(\mathrm{CH}=\mathrm{CH}-\mathrm{C}=\mathrm{O})$. JEOL JMS 600, $\mathrm{EI}^{+}$mode: $m / z=268.2615[\mathrm{M}]^{+}, 269.2657[\mathrm{M}+\mathrm{H}]^{+}$.

(3a) N,N-Dimethylcinnamamide. $73.34 \%$ yield, ${ }^{1} \mathrm{H}$ NMR $\left(\mathrm{CDCl}_{3}, 300 \mathrm{MHz}, 298 \mathrm{~K}\right) \delta(\mathrm{ppm}): 7.66-7.71(\mathrm{~d}, 1 \mathrm{H}, J=$ $15.6 \mathrm{~Hz}, \mathrm{CH}=\mathrm{CH}), 7.53(\mathrm{~d}, 2 \mathrm{H}, J=7.8 \mathrm{~Hz}, \mathrm{Ar}-\mathrm{H}), 7.35(\mathrm{~m}$, $3 \mathrm{H}, \mathrm{Ar}-\mathrm{H}), 6.68(\mathrm{~d}, 1 \mathrm{H}, J=15.0 \mathrm{~Hz}, \mathrm{CH}=\mathrm{CH}), 3.12(\mathrm{~s}, 6 \mathrm{H}$, $\left.-\mathrm{CH}_{3}\right) .{ }^{13} \mathrm{C}$ NMR $\left(300 \mathrm{MHz}, \mathrm{CDCl}_{3}\right): 167.0(\mathrm{C}=\mathrm{O}), 142.9(\mathrm{Ar}-$ $\mathrm{CH}=\mathrm{CH}), 135.5,129.8,129.0,128.0(\mathrm{Ar}), 117.3(\mathrm{CH}=\mathbf{C H}-\mathrm{C}=\mathrm{O})$, $37.0\left(\mathrm{CH}_{3}\right)$. JEOL JMS 600, $\mathrm{EI}^{+}$mode: $m / z=175.0993[\mathrm{M}]^{+}$, $176.1403[\mathrm{M}+\mathrm{H}]^{+}$.

(3b) N,N-Diethylcinnamamide. $76.85 \%$ yield, ${ }^{1} \mathrm{H}$ NMR $\left(\mathrm{CDCl}_{3}, 300 \mathrm{MHz}, 298 \mathrm{~K}\right) \delta(\mathrm{ppm}): 7.73(\mathrm{~d}, 1 \mathrm{H}, J=15.9 \mathrm{~Hz}$, $\mathrm{CH}=\mathrm{CH}), 7.55(\mathrm{~m}, 2 \mathrm{H}, J=7.8 \mathrm{~Hz}, \mathrm{Ar}-\mathrm{H}), 7.39(\mathrm{~m}, 3 \mathrm{H}, \mathrm{Ar}-\mathrm{H})$, $6.85(\mathrm{~d}, 1 \mathrm{H}, J=15.0 \mathrm{~Hz}, \mathrm{CH}=\mathrm{CH}), 3.40-3.50\left(\mathrm{~m}, 4 \mathrm{H}, \mathrm{CH}_{2}\right)$, $1.25\left(\mathrm{~m}, 6 \mathrm{H}, \mathrm{CH}_{3}\right) \cdot{ }^{13} \mathrm{C}$ NMR $\left(300 \mathrm{MHz}, \mathrm{CDCl}_{3}\right): 165.7$ $(\mathbf{C}=\mathrm{O}), 142.3(\mathrm{Ar}-\mathrm{CH}=\mathrm{CH}), 135.5,129.4,128.7,127.7(\mathrm{Ar}), 117.7$ $(\mathrm{CH}=\mathrm{CH}-\mathrm{C}=\mathrm{O}), 42.3\left(\mathrm{CH}_{2}-\mathrm{CH}_{3}\right), 13.2\left(-\mathrm{CH}_{3}\right)$. JEOL JMS 600, $\mathrm{EI}^{+}$mode: $m / z=203.2913[\mathrm{M}]^{+}, 204.2732[\mathrm{M}+\mathrm{H}]^{+}$.

2.2. Antimicrobial Activity. The antimicrobial activity of the synthesized compounds was tested in vitro against twentyone microorganisms. Stock solutions $(1 \mathrm{mg} / \mathrm{mL})$ of synthesized compounds $\mathbf{2 a}-\mathbf{2} \mathbf{g}$ and $\mathbf{3 a} \mathbf{a}-\mathbf{3 b}$ were prepared by dissolving each compound in dimethyl sulfoxide. Calculated volumes of stock solutions were dispensed in series of McCartney bottles previously containing calculated volumes of sterile cooled molten nutrient agar media $\left(40-45^{\circ} \mathrm{C}\right)$ to prepare the volume of $30 \mathrm{~mL}$ each with dilutions of $5,10,25,50,100$, 200,400 , and $800 \mu \mathrm{g} / \mathrm{mL}$. These sterile nutrient agar media solutions were poured into Petri plates and allowed to solidify. These plates were kept in the refrigerator at $4^{\circ} \mathrm{C}$ for $24 \mathrm{~h}$ to allow the uniform diffusion of the compounds throughout the nutrient agar medium. Before spot inoculation, plates were kept at $37^{\circ} \mathrm{C}$ for $2 \mathrm{~h}$. One loop full (loop diameter: $3 \mathrm{~mm}$ ) of an overnight grown peptone water culture of each microorganism was inoculated, and the location of the inoculation was marked by the checkerboard technique. The spot inoculated plates were incubated at $37^{\circ} \mathrm{C}$ for $24 \mathrm{~h}$ and the minimum inhibitory concentration (MIC, $\mathrm{mM}$ ) values were obtained. The calculated pMIC $\left(-\log _{10}\right.$ MIC) values are presented in Table 1. Experiments were done in triplicate, and the results were presented as mean values of the three measurements. 
2.3. Antioxidant Activity. The antioxidant activity of the synthesized compounds (2a-2g, 3a-3b) was evaluated using the DPPH free radical scavenging assay [18]. The $200 \mu \mathrm{L}$ of test sample solution $(1 \mathrm{mg} / \mathrm{mL})$ was added to $4 \mathrm{~mL}$ of $100 \mu \mathrm{M}$ methanolic DPPH. The solution was allowed to incubate for 20 minutes at $25^{\circ} \mathrm{C}$, and the absorbance was measured at $517 \mathrm{~nm}$. Ascorbic acid $(1 \mathrm{mg} / \mathrm{mL})$ was used as reference standard. A blank was prepared without adding the standard or test compound. The lower absorbance of the reaction mixture indicates higher free radical scavenging activity. The capability to scavenge the DPPH radical was calculated using the following equation:

$$
\% \text { inhibition }=\frac{A_{\text {control }}-A_{\text {sample }}}{A_{\text {control }}} \times 100,
$$

where $A_{\text {control }}$ is the absorbance of the DPPH alone and $A_{\text {sample }}$ is the absorbance of DPPH in the presence of compounds $\mathbf{2 a - 2}$, $\mathbf{3 a - 3}$. All determinations were performed in triplicate $(n=3)$. The results are presented in Figure 1 .

\section{Results and Discussions}

3.1. The Synthesis. The amide derivatives of cinnamic acid $2 \mathbf{a}-$ $\mathbf{2 g}$ and $\mathbf{3 a} \mathbf{a}-\mathbf{3 b}$ were synthesized to study the effect of amide nitrogen substituents on the antimicrobial activity. As shown in Scheme 1, the reaction of cinnamoyl chloride with corresponding aromatic or aliphatic amines gave compounds $\mathbf{2 a -}$ $\mathbf{2 g}$ and $\mathbf{3 a - 3 b}$. All compounds were obtained in good yield, purified by recrystallization, and characterized by ${ }^{1} \mathrm{H} \mathrm{NMR}$, ${ }^{13} \mathrm{C}$ NMR, and mass spectrometry.

3.2. Antimicrobial Activity. The pMIC (- $\log (\mathrm{MIC}))$ values of compounds $\mathbf{2 a - 2 g}, \mathbf{3 a - 3} \mathbf{b}$ are presented in Table 1. Except compound 2d, all compounds showed a good antibacterial activity against Gram-negative compared to Gram-positive bacterial strains. Compound $\mathbf{2} \mathbf{b}$ showed strong antimicrobial activity against all microorganisms with the pMIC values ranging from 2.78 to 3.68. However, compound $2 \mathrm{~d}$ demonstrated little ( $\mathrm{pMIC}=2.58$ ) or no antibacterial activity in the tested concentration domain. Similarly, compound $\mathbf{3 a}$ also showed very poor or no antimicrobial activity against the tested microorganisms. Therefore, compounds $\mathbf{2 d}$ and $\mathbf{3 a}$ were considered as poor antimicrobial compounds. Compounds $\mathbf{2 c}, \mathbf{2 e - 2}$ showed the highest antimicrobial activity against E. coli LT37 with the pMIC of 4.03-4.43. Moreover, compounds $\mathbf{2} \mathbf{e}$ and $\mathbf{2} \mathbf{f}$ demonstrated strong activity against Vibrio cholerae 85 and Staphylococcus aureus ML267, respectively.

Compound 2a demonstrated strongest activity against E. coli LT37, Salmonella Typhi Ty2, Vibrio cholerae 85, and Bacillus subtilis ATCC 6633 with the pMIC value of 3.95 . Compound $\mathbf{2 b}$ showed strong activity against all microorganisms except for Shigella dysenteriae 1, Shigella sonnei 1, and Staphylococcus aureus ML267 with the lowest pMIC value of 2.78. Compound $2 \mathrm{c}$ did not show any antibacterial activity against Shigella sonnei 1 and Bacillus pumilus 82. Compound 3b showed the strongest activity against E. coli LT37 and Shigella boydii D13629 with the pMIC of 3.85 .

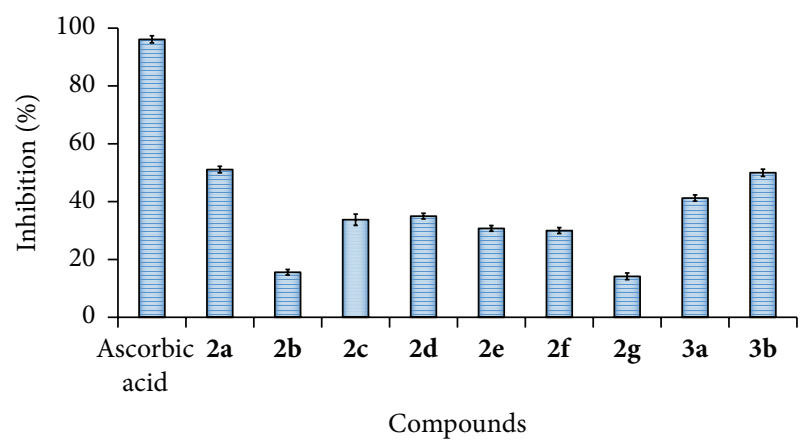

FIGURE 1: DPPH radical scavenging activity of compounds $\mathbf{2 a - 2} \mathbf{g}$ and $\mathbf{3 a}-\mathbf{3 b}$.

From the results of the microbiological studies, it is evident that substituents on the amide nitrogen of cinnamamide derivatives $\mathbf{2} \mathbf{a}-\mathbf{2} \mathbf{g}$ and $\mathbf{3 a} \mathbf{a} \mathbf{3 b}$ play a critical role in their antimicrobial activities. Derivatives $\mathbf{2} \mathbf{a}-\mathbf{2} \mathbf{g}$ and $\mathbf{3 a} \mathbf{a} \mathbf{3} \mathbf{b}$ were obtained from primary amines (aniline derivatives) and secondary amines, respectively. It is important to notice that compound $\mathbf{2 b}$, which contains $o$-hydroxyphenyl substituent on the amide nitrogen, showed a significant increase in the antimicrobial activity as compared to compound $\mathbf{2 a}$, which contains only phenyl group. Compound $2 c$ containing $p$ chlorophenyl substituent on the amide nitrogen showed strong activity as compared to compound $\mathbf{2 d}$, which contains p-bromophenyl substitution on the amide nitrogen. Among the compounds containing the nitrophenyl substituents on the amide nitrogen, compound $2 \mathbf{e}$ showed strong activity as compared to compounds $\mathbf{2} \mathbf{f}$ and $\mathbf{2 g}$. The $m$-nitrophenyl substituent in compound $\mathbf{2} \mathbf{e}$ endows it with a strong antibacterial activity as compared to the $o$-nitrophenyl and $p$-nitrophenyl substituents in compounds $\mathbf{2} \mathbf{f}$ and $\mathbf{2 g}$, respectively. It is also important to notice that the aromatic substituents on the amide nitrogen allow overall strong activity as compared to the aliphatic substituents. The presence of bulky ethyl groups on the amide nitrogen of compound $\mathbf{3 b}$ allows it to demonstrate strong activity as compared to compound $\mathbf{3 b}$ containing methyl groups.

3.3. Antioxidant Activity. DPPH radical scavenging is considered as a good in vitro model and is widely used to assess antioxidant efficacy $[19,20]$. The DPPH free radical scavenging assay was employed to evaluate the antioxidant activity of the synthesized compounds. The DPPH radical scavenging activity of compounds $\mathbf{2 a - 2 g}$, $\mathbf{3 a - 3} \mathbf{b}(50 \mu \mathrm{g} / \mathrm{mL})$ was compared with that of ascorbic acid at the same concentration. As presented in Figure 1, the results of antioxidant screenings were expressed as \% of inhibition of the DPPH radical.

As depicted in Figure 1, most compounds showed moderate-to-good antioxidant activity. Compounds 2a, 3a, and 3b showed strong activity as indicated by the \% inhibition of the DPPH radical, $51 \%( \pm 1.14), 41 \%( \pm 1.01)$, and $50 \%$ $( \pm 1.23)$, respectively. Compounds $\mathbf{2 b}$ and $\mathbf{2 g}$ showed very low activity with the $\%$ inhibition of $16 \%( \pm 1.12)$ and $14 \%( \pm 1.09)$, respectively. Compounds $\mathbf{2 c}, \mathbf{2 d}, \mathbf{2 e}$, and $\mathbf{2 f}$ showed moderate activity with the $\%$ inhibition of $34 \%( \pm 1.96), 35 \%( \pm 0.98)$, 
$31 \%( \pm 0.97)$, and $30 \%( \pm 1.02)$, respectively. The results clearly indicate the electron donating groups on the amide nitrogen (3a-3b) play an important role in scavenging the free radicals. Moreover, compound $\mathbf{2 a}$, which contains phenyl group on amide nitrogen, demonstrates almost similar radical scavenging activity to that of compounds $\mathbf{3 a}, \mathbf{3} \mathbf{b}$, which contain dimethyl and diethyl substituents on amide nitrogen, respectively.

However, the electron withdrawing substituents such as $p$-chloro, $p$-bromo, and $o$-nitro, $m$-nitro, and $p$-nitro on phenyl ring in compounds $\mathbf{2 c}, \mathbf{2} \mathbf{d}$, and $\mathbf{2 e - 2 g}$, respectively, significantly decrease radical scavenging activity. The results obtained in this study are in line with other findings [21].

\section{Conclusion}

Most of the amide derivatives of cinnamic acid mentioned in this showed moderate-to-high antibacterial and antioxidant activities. The investigation of antimicrobial potentials of the compounds demonstrated a strong activity against 21 bacterial strains comprising Gram-positive and Gram-negative bacteria. Compounds $\mathbf{2 a}, \mathbf{2} \mathbf{b}$, and $\mathbf{3} \mathbf{b}$ showed strong antimicrobial activity against all microorganisms with the pMIC value ranging from 2.45 to 3.68. Compounds 2a, 3a, and $3 \mathbf{b}$ demonstrated strong antioxidant activity. These findings encourage the synthesis of new amide derivatives of cinnamic acid. These findings indicate that the amide derivatives of the cinnamic acid afford strong antibacterial and antioxidant activities.

\section{Conflict of Interests}

All authors declare that there is no conflict of interests.

\section{Acknowledgment}

This research was supported by the Hallym University Research Fund (HRF-201504-018).

\section{References}

[1] T. Hintz, K. K. Matthews, and R. Di, "The use of plant antimicrobial compounds for food preservation," BioMed Research International, vol. 2015, Article ID 246264, 12 pages, 2015.

[2] A. Lucera, C. Costa, A. Conte, and M. A. Del Nobile, "Food applications of natural antimicrobial compounds," Frontiers in Microbiology, vol. 3, article 287, 2012.

[3] K. W. Lee and G. Y. H. Lip, "The role of omega-3 fatty acids in the secondary prevention of cardiovascular disease," QJM, vol. 96, no. 7, pp. 465-480, 2003.

[4] H.-S. Wu, W. Raza, J.-Q. Fan, Y.-G. Sun, W. Bao, and Q.-R. Shen, "Cinnamic acid inhibits growth but stimulates production of pathogenesis factors by in vitro cultures of Fusarium oxysporum f.sp. niveum," Journal of Agricultural and Food Chemistry, vol. 56, no. 4, pp. 1316-1321, 2008.

[5] K. Bagchi and S. Puri, "Free radicals and antioxidants in health and disease," EMHJ-Eastern Mediterranean Health Journal, vol. 4, no. 2, pp. 350-360, 1998.
[6] Y.-W. Kim and T. V. Byzova, "Oxidative stress in angiogenesis and vascular disease," Blood, vol. 123, no. 5, pp. 625-631, 2014.

[7] I. S. Young and J. V. Woodside, "Antioxidants in health and disease," Journal of Clinical Pathology, vol. 54, no. 3, pp. 176-186, 2001.

[8] D. K. Pal and S. B. Nimse, "Screening of the antioxidant activity of Hydrilla verticillata plant," Asian Journal of Chemistry, vol. 18, no. 4, pp. 3004-3008, 2006.

[9] H.-J. Suh, M.-S. Chung, Y.-H. Cho et al., "Estimated daily intakes of butylated hydroxyanisole (BHA), butylated hydroxytoluene (BHT) and tert-butyl hydroquinone (TBHQ) antioxidants in Korea," Food Additives and Contaminants, vol. 22, no. 12, pp. 1176-1188, 2005.

[10] S. Lafay and A. Gil-Izquierdo, "Bioavailability of phenolic acids," Phytochemistry Reviews, vol. 7, no. 2, pp. 301-311, 2008.

[11] M. N. Clifford, "Chlorogenic acids and other cinnamatesnature, occurrence, dietary burden, absorption and metabolism," Journal of the Science of Food and Agriculture, vol. 80, no. 7, pp. 1033-1043, 2000.

[12] P. De, M. Baltas, and F. Bedos-Belval, "Cinnamic acid derivatives as anticancer agents-a review," Current Medicinal Chemistry, vol. 18, no. 11, pp. 1672-1703, 2011.

[13] P. Sharma, "Cinnamic acid derivatives: a new chapter of various pharmacological activities," Journal of Chemical and Pharmaceutical Research, vol. 3, no. 2, pp. 403-423, 2011.

[14] M. Sova, "Antioxidant and antimicrobial activities of cinnamic acid derivatives," Mini-Reviews in Medicinal Chemistry, vol. 12, no. 8, pp. 749-767, 2012.

[15] S. Vishnoi, V. Agrawal, and V. K. Kasana, "Synthesis and structure-activity relationships of substituted cinnamic acids and amide analogues: a new class of herbicides," Journal of Agricultural and Food Chemistry, vol. 57, no. 8, pp. 3261-3265, 2009.

[16] C. Sánchez-Moreno, "Review: methods used to evaluate the free radical scavenging activity in foods and biological systems," Food Science and Technology International, vol. 8, no. 3, pp. 121137, 2002.

[17] T.-C. Wang, Y.-L. Chen, K.-H. Lee, and C.-C. Tzeng, "Lewis acid catalyzed reaction of cinnamanilides: competition of intramolecular and intermolecular Friedel-Crafts reaction," Synthesis, no. 1, pp. 87-90, 1997.

[18] C. Sánchez-Moreno, J. A. Larrauri, and F. Saura-Calixto, "A procedure to measure the antiradical efficiency of polyphenols," Journal of the Science of Food and Agriculture, vol. 76, no. 2, pp. 270-276, 1998.

[19] M. Oktay, I. Gülçin, and Ö. I. Küfrevioğlu, "Determination of in vitro antioxidant activity of fennel (Foeniculum vulgare) seed extracts," LWT-Food Science and Technology, vol. 36, no. 2, pp. 263-271, 2003.

[20] S. B. Nimse and D. Pal, "Free radicals, natural antioxidants, and their reaction mechanisms," RSC Advances, vol. 5, no. 35, pp. 27986-28006, 2015.

[21] H. M. Ali, A. Abo-Shady, H. A. S. Eldeen et al., "Structural features, kinetics and SAR study of radical scavenging and antioxidant activities of phenolic and anilinic compounds," Chemistry Central Journal, vol. 7, no. 1, article 53, 9 pages, 2013. 

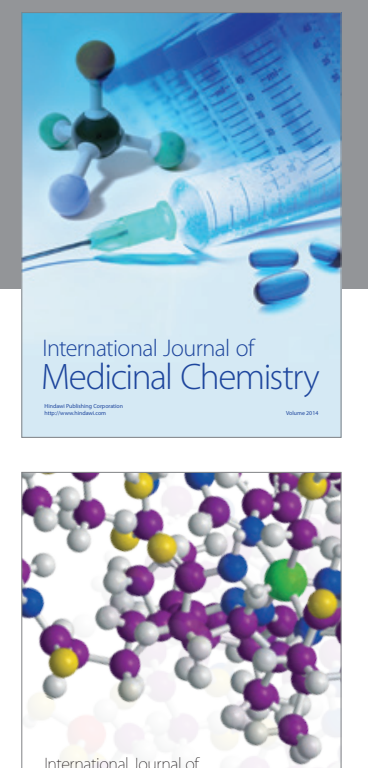

\section{Carbohydrate} Chemistry

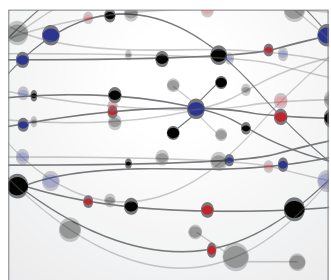

The Scientific World Journal
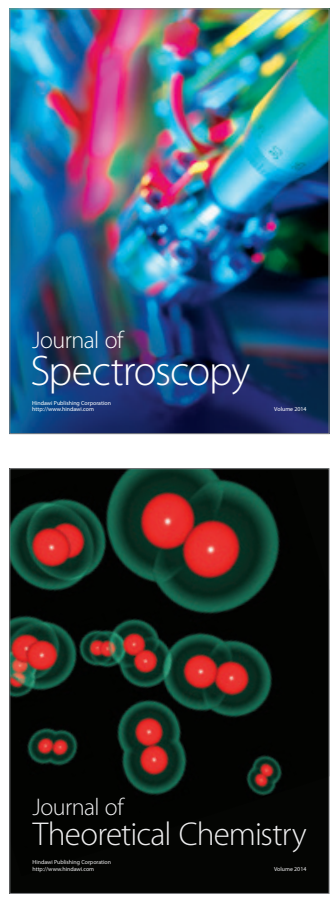
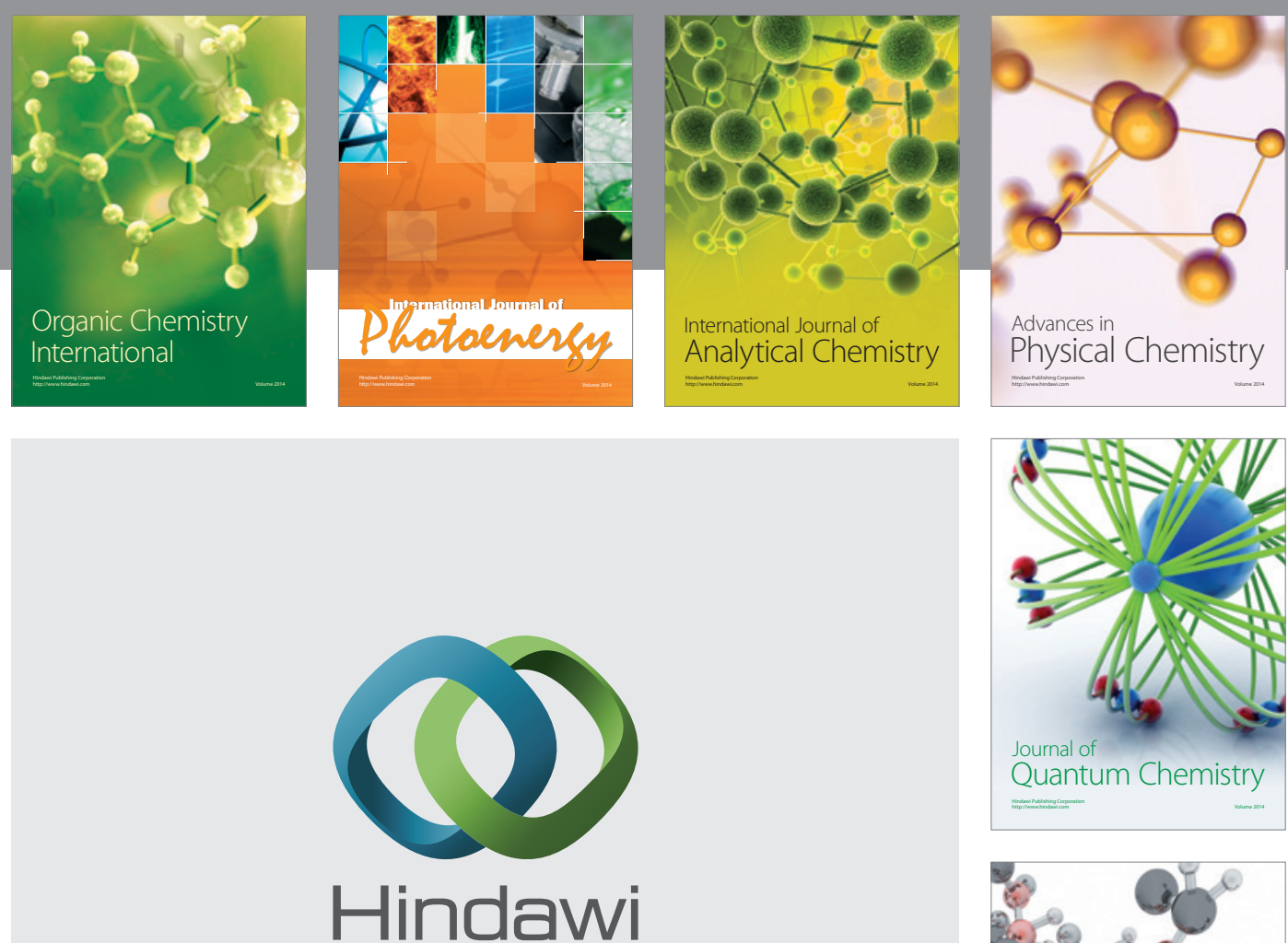

Submit your manuscripts at

http://www.hindawi.com

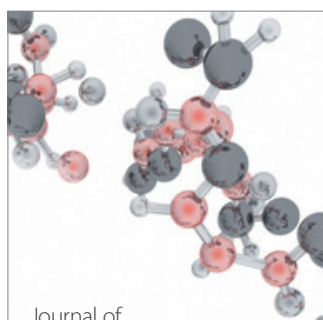

Analytical Methods

in Chemistry

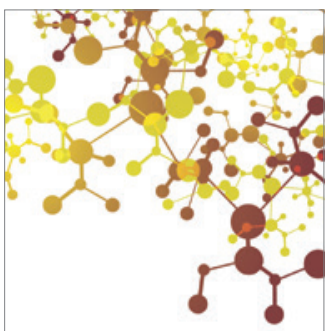

Journal of

Applied Chemistry

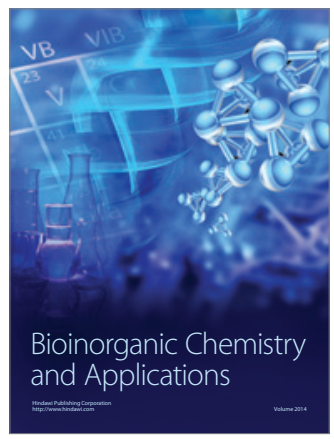

Inorganic Chemistry
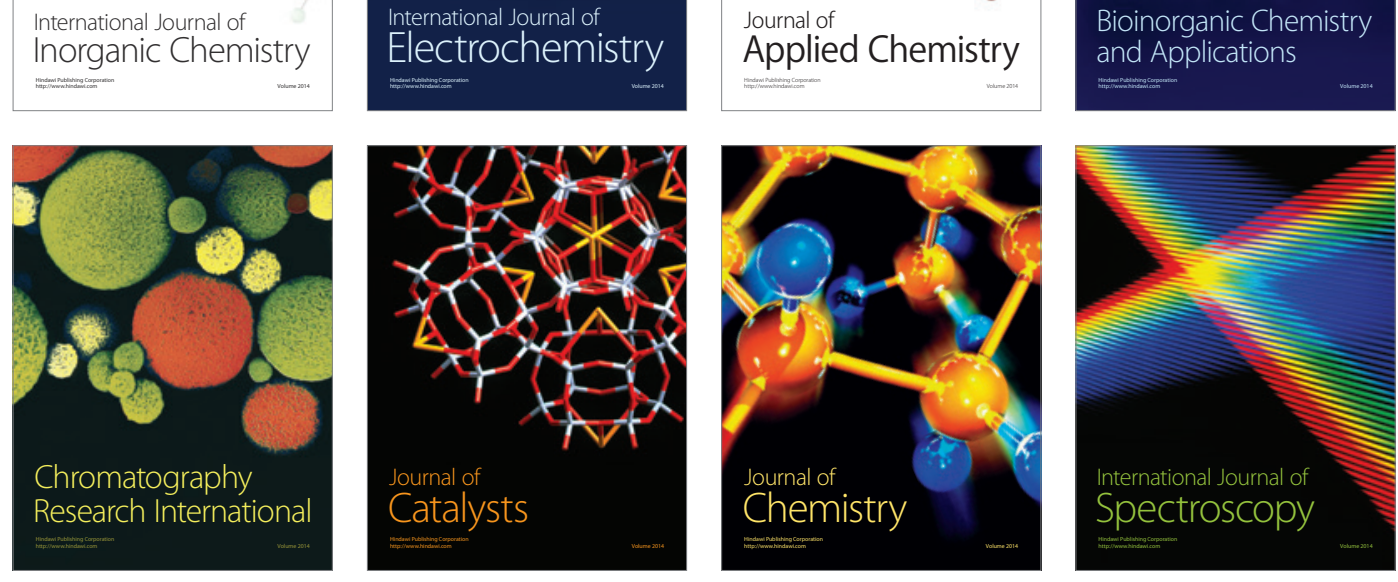